\title{
Redolent landscapes
}

This issue of arq is devoted to the discussion of designed landscapes, gardens and their relationship to architecture and urban environments - both in history and in contemporary practice. Three of the papers presented here were first delivered at a session titled 'Water and the Soul' at the American Society of Architectural Historians annual meeting in Chicago (with or without their author's presence, courtesy of the Icelandic volcano which grounded European air travel): Nina Hofer gives an interpretation of the short-lived Grotto of Thetys at Versailles, bringing together the idea of the power of the water handled there with the puissance of the King, Louis XIV and the courtly ritual of entertainments; John Dixon Hunt, in his short piece, documents a change in the mode of animation sought in water-effects in the passage from late Renaissance to eighteenth-century European gardens; and Juliet Odgers interprets a series of drawings by John Evelyn of his family's estate at Wotton, as a record of what he understood as a philosophical domain that embraced both the formal gardens and the hydraulic trade landscape of the wider estate.

Rona Lee presents and reflects on her own art practice, also taking water as her theme. The dark of the deep ocean bed is her site. What is it to bring to visibility a space that is both unseen and uninhabitable, where the pressure of the water will compress metal and fiery vents consume durable plastic in seconds? Lee worked alongside a group of scientists who regularly delineate the deep ocean through bathymetrics and data mapping. Her art is a response to the idea of immersions, the adventure of going beyond and to the strange world of data collection and modelling. What, she asks, is denied in these scientists'

representations of an ocean bed drained and illuminated?

With Annette Condello's paper, 'Sybaris is the land where it wishes to take us', we return to France for a discussion of buildings in terms of image, vista and morality. A group of garden buildings were conceived by their makers and perceived by their detractors with reference to the lost city of Sybaris, a mythical locus of moral laxity. The gardens' sybaritic places were seen either as loci of pleasure and luxury; or of debauchery and excess - depending on the point of view. Dressed in architectural costumes of rural simplicity or antique ruination, the garden structures could be seen as charming conceits or, for their critics - as costly and immoral deceits.

The shadow of Adam in paradise hangs over the discussion of the regenerative potential of the gardener and the act of gardening, evoked by Graham Livesey in his discussion of the legacy of Ebenezer Howard's ideas and the first Garden Cities. Against sprawling suburbs, ecological catastrophe and desert-like city 'green space', Livesey proposes the remedy of a 
city modelled on a garden tended by gardeners - not maintenance contractors. The ecological diversity of gardens and the care and engagement of gardeners with the husbandry of their territories might serve as inspiration for a model city and model citizens.

This thought comes close to one of the concerns that motivates David Leatherbarrow's 'Agenda' piece, 'Is Landscape Architecture?'. Leatherbarrow argues that ecology is not in opposition to culture or separate from culture but rather that ecology is cultural. Human actions, human thought, human culture can be integral to and useful to an ecology. Leatherbarrow also provides us with a historical perspective against which to gauge current claims for the originality of integrating landscape architecture with architecture and urban design. Summarising the long tradition of this integrated approach, Leatherbarrow provides the grounds for an appreciation of what is distinct and new about current work, focusing his argument around two recent urban landscape projects in the us Freshkills Park in New York City by James Corner Field Operations and Seattle Olympic Sculpture Park by Weiss/Manfredi - both of which are presented as examples of 'topographies' that provide a rich setting that 'articulates beautifully' the patterns of our everyday lives.

THE EDITORS 